\title{
以党建主题教育实践为抓手 探索党员教育新路径
}

\author{
梅元媛 石玉枝 \\ 上海工程技术大学 \\ DOI:10.32629/mef.v3i1.512
}

[摘 要] 中国特色社会主义进入新时代, 以习近平同志为核心的党中央作出全面从严治党的战略部署, 对高校党建提出了 新要求。本研究以“不忘初心、牢记使命” 主题教育实践为研究重点, 以“加强主题性阵地建设”为主攻方向。通过加强新 阵地建设、网络新媒体建设和党支部队伍建设，探索党员教育的新路径，切实提高党员教育。

[关键词] 主题教育; 实践载体; 党员教育

\section{Taking Party Construction Theme Education Practice as a Hand to Explore a New Path of Party Member Education}

Mei Yuanyuan, Shi Yuzhi

Shanghai University of Engineering Science

[Abstract] Socialism with Chinese characteristics has entered a new era, the Party Central Committee with Comrade $\mathrm{Xi}$ Jinping as its core has made a comprehensive strategic plan to administer the party strictly and has set new requirements for party building in colleges and universities. This research focuses on the educational practice of the theme of "do not forget the original heart and keep in mind the mission" , and focuses on "strengthening thematic positions”. By strengthening the construction of new positions, the construction of new media on the Internet, and the building of party branch teams, new paths for party member education are explored to effectively improve party member education.

[Keywords] theme education; practice carrier; party member education

高校党建是党的建设新的伟大工程的重要组织部分。中 国特色社会主义进入新时代, 以习近平同志为核心的党中央 作出全面从严治党的战略部署, 对高校党建提出了新要求。 深入贯彻落实党的十九大精神和习近平总书记系列重要讲 话精神, 积极探索党建工作的新思路、新方法、新举措, 探 索党员教育新路径, 切实提高党员教育质量。本研究以 “不 忘初心、牢记使命” 主题教育实践为研究重点, 以 “加强主 题性阵地建设” 为主攻方向, 通过加强新阵地建设、网络新 媒体建设和党支部队伍建设, 探索党员教育的新路径, 切实 提高党员教育。

\section{1 以思想教育为核心, 注重政治引领}

1. 1 学经典一一依托红色经典, 提高党员理论水平。以 “读书分享会” 的形式, 让党员品读学习红色书籍和研读习 近平总书记重要讲话, 以主角身份站上舞台, 分享体会。以 “党支部书记讲党课” 的形式, 不断提升党支部书记的政治 素养、理论水平、党性修养和党务工作能力, 以带领提升党 员教育工作的水平。

1.2 议时政——聚焦时政热点, 提升党员政治素养。开 展 “两会知识竞答活动”、观看十九大开幕式、“十九大新党 章学习” 系列报道专题组织生活会等活动。通过思想政治教 育与理论学习、时政热点相结合, 团结引领各党员听党话、 跟党走, 不断提高学生党员的政治素养、思想成熟度和理论
水平。

\section{2 以实践教育为抓手, 探索党员教育新路径}

2. 1 新阵地一一加强主题性阵地建设。党建阵地建设, 一方面, 挖掘红色资源, 包括活动遗址、纪念馆等红色基地, 以这些阵地为新 “讲台”, 开展 “我是党史主讲人” 专题活 动, 通过丰富的场景体验, 增强党员对红色资源的价值认同 感, 提高党员的政治思想。另一方面, 立足专业优势, 引入 新思维, 鼓励带着党员队伍走出校门, 学习其他先进单位党 建模式和管理制度。学院党支部与南通市五接镇举行党组织 共建活动, 提升组织力, 提高基层党建质量。

2.2 新载体一一加强网络新媒体建设。党建媒体建设, 要 创新工作模式, 利用好微信公众平台、易班平台, “学习强国” 手机客户端等新媒体方式, 充分调动师生党员参与党组织活 动的积极性和主动性。同时, 要加强网络和新媒体阵地的管 理和监督机制, 确保网络安全, 促进党建工作有序开展。

2.3 新重点——加强党中青年教师培养。党支部队伍建 设, 要重视和落实青年教师 “课程思政” 建设, 为青年党员 教师配备职业导师, 导师均由学院党员领导干部、党委委员 和党支部书记担任, 厚植政治信仰根基, 筑牢思政育人高地。 深培 “双带头人” 制, 发挥带头人作用, 定期进行书记谈心 谈话, 带优党支部队伍。

3 以党员获得感为延伸, 提高党员教育质量 
以主题教育为载体, 遵循 “政治性”、“先进性” 和 “服 务性” 原则, 通过 “学”、“思”、“行” 的方式, 引导学生党 员学精、学细、学根、学源、学深、学实。通过提升青年教 师党员和学生党员在党员教育中的获得感、责任荣誉感和使 命感, 实现 “知识思想”、“情感体验”、“意志品质” 和 “实 践行动” 四个层面的成长, 切实提高党员教育的质量和实效 性, 提升凝聚力、感召力和影响力, 拓宽党员教育新领域, 提升党员教育新水平。

3.1 聚焦经典原著, 拓展知识广度

通过 “导学”、“研学”、“比学” 的方式, 党员自学原原 本本学, 扎扎实实学原著, 读书分享交流会的形式, 把学习 贯穿始终。党员集中学: 深学细悟、融会贯通, 以理论滋养 初心, 以理论引领使命。此外, 用好 “学习强国”、“易班” 等平台, 开展 “比学习、评积分、提素养” 以及 “党员晒 积分” 活动, 鼓励学生党员学习, 互帮互促, 提高理论水 平与素质。举办 “知识竞答” 活动, 扎实抓好党员学习教育, 做好党员学习督促工作, 加强理论知识学习, 增强学习教育 的针对性、时效性、感染力。用习近平新时代中国特色社会 主义思想教育引导青年党员, 突出问题意识, 引导党员自觉 关注当代中国和世界现实, 认真贯彻落实党的理论和路线方 针政策, 拓展党员知识的广度, 激发学习潜能。

3.2 着眼党员体验, 增强情感厚度

开展活动与党员关注的热点相结合, 引导党员在 “做中 思”、“讲中思”、“践中思”。学院培育 “百炼成钢材料人, 伟大复兴中国梦” 大学生新思想宣讲团队, 立足专业, 挖掘 习近平新时代中国特色社会主义思想中的精髓, 找到与专业 的切合点, 讲述材料的进步给国家和人民带来的重大发展, 引导党员用自己的满腔热血为科技兴军、国家发展贡献自己 的力量, 将个人梦融入国家梦, 为实现中华民族伟大复兴的 中国梦不解奋斗。以此来提高党员教育的亲和力, 增强情感 表达力的主观体验。

此外, 利用读书分享会的形式, 以学生党员分享、教师 党员点评的方式进行, 选取经典书籍中的片段、故事, 细品 研读, 教师把立德树人作为根本任务, 在坚定理想信念、厚 植爱国情怀、加强品德修养、增长知识见识、培养奋斗精神、 增强综合素质六个方面上下功夫, 引领学生党员能够坚守初 心，终身奋斗，全力培养社会主义建设者和接班人。

3. 3凝聚信仰力量, 锤炼意志韧度

信仰是是指导人的行动的精神动力和精神支柱, 通过红 色经典读书会活动、党课党史研究, 缅怀抗战英烈、感受革 命烽火, 以理论滋养初心, 筑牢信仰之基。通过开展 “守望
初心，砥研前行” 中共一大会址、遵义会议纪念馆主题展览 参观交流, 观看电影 “我和我的祖国” 等活动, 教育引导学 生党员坚定对马克思主义的信仰、对中国特色社会主义的信 念, 传承红色基因, 激励学生自觉把个人的理想追求融入国 家和民族的事业中。来凝聚青年党员信仰的力量, 锻炼意志 品质, 激发潜能, 实现个体发展, 鼓励党员牢固树立理想信 念, 跟上新时代的步伐、勇往直前。

3. 4 立足自身成长, 提升行动力度

重视青年党员的感性体验, 让党员在实践教育中再次加 深对理论的理解，提高在现实社会中分析问题和解决问题的 能力。切实做到立足于联系实际，立足于本职工作。把理想 信念融入到平凡的工作中, 发挥党员先锋模范作用, 为身边 群众办实事好事, 以实际行动践行初心和使命。学院学生党 支部积极开展 “程园领路人” 入党启蒙教育活动, 于园区设 立党员先锋服务工作站, 走进园区开展入党启蒙服务咨询, 增进新生对党的基本知识的理解和认识, 提升新生的政治思 想觉悟, 进一步引导全院新生正确看待入党问题, 详细了解 入党流程, 加强了党支部与同学们的沟通与联系。开展 “关 爱自闭症儿童、志愿服务我在行动“党员主题党日志愿活动, 引导党员能立足社会、关心社会问题和社会发展, 为人民服 务, 增强志愿服务意识、责任感和奉献精神。

此外, 开展支部实践活动, 党员骨干深入学生宿舍、课 堂, 与入党申请者、积极分子谈话, 准确了解、掌握学生的 基本情况和思想动态, 及时倾听学生的心声, 努力解答学 生的疑问, 妥善解决学生遇到的实际问题, 提升青年党员的 行动力度。通过党校、团校、新生交流会、党员先锋岗、党 员亮身份等多个渠道, 以优秀党员讲坛、党团系列交流会、 新老党员座谈会等为平台, 不仅在支部内部形成相互监督、 提升自我, 完善自我的良好氛围; 并以党建带团建, 也在思 想、学习、工作、实践各方面为普通同学做出表率, 充分发 挥支部党员的先锋模范作用。

\section{[参考文献]}

[1]陈殿林。“不忘初心、牢记使命” 主题教育的实践逻 辑[J],中国特色社会主义研究,2019(03):11-16.

[2]陈怡,周文娜。“双融合”型高校学生党建工作模式的 实践探索[J], 江苏高教,2019(01):107-110.

\section{作者简介:}

梅元媛（1979-- ), 女，汉族，河南洛阳人，副教授， 研究生，研究方向：思想政治教育。

石玉枝（1991--)，女，汉族，山东邹平人，讲师，研 究生，研究方向:思想政治教育。 